$4-26-2018$

\title{
Patients Are Our Teachers
}

Robert E. Becker

Mary V. Seeman

Follow this and additional works at: https://aah.org/jpcrr

Part of the Bioethics and Medical Ethics Commons, Medical Education Commons, Medical Humanities Commons, and the Public Health Commons

\section{Recommended Citation}

Becker RE, Seeman MV. Patients are our teachers. J Patient Cent Res Rev. 2018;5:183-6. doi: 10.17294/ 2330-0698.1589

Published quarterly by Midwest-based health system Advocate Aurora Health and indexed in PubMed Central, the Journal of Patient-Centered Research and Reviews (JPCRR) is an open access, peer-reviewed medical journal focused on disseminating scholarly works devoted to improving patient-centered care practices, health outcomes, and the patient experience. 


\title{
TOPIC SYNOPSIS
}

\section{Patients Are Our Teachers}

\author{
Robert E. Becker, MDCM, MA, ${ }^{1,2}$ Mary V. Seeman, MDCM, DSc ${ }^{3}$ \\ ${ }^{1}$ Aristea Translational Medicine Corporation, Park City, UT; ${ }^{2}$ Translational Gerontology Branch, Intramural Research \\ Program, National Institute on Aging, Baltimore, MD; ${ }^{3}$ Department of Psychiatry, Institute of Medical Science, \\ University of Toronto, Toronto, Canada
}

\begin{abstract}
In the patient-physician encounter, physicians hone their skills while alleviating the patient's suffering. Both benefit. Leaning on the work of Hippocrates, Darwin, and William Osler, the authors sketch out the case for honoring patients as indispensable teachers of the art and science of medicine. They argue that this tradition of Hippocratic medicine both anticipates modern precision medicine and reawakens a focus on public health medicine, each a benefit to the patients and communities served by physicians. A community that compromises the learning relationship of physician to patient and population undermines quality of care. (J Patient Cent Res Rev. 2018;5:183-186.)
\end{abstract}

Keywords patient-physician relationship; Hippocrates; Darwin; Osler; population medicine; public health

"He who studies medicine without books sails an uncharted sea, but he who studies medicine without patients does not go to sea at all." I

\section{- William Osler}

$\mathrm{P}$ hysicians will do well to remember that the Hippocratic Oath exhorts us to respect our teachers: "To hold my teacher in this art equal to my own parents; to make him partner in my livelihood; when he is in need of money to share mine with him."2 What light does this throw on the physician-patient relationship? Hippocrates teaches us that the doctor, as lifelong learner, owes a debt to patients and the larger community to which they belong. The Hippocratic Corpus makes clear that patient care will be incomplete if it does not consider both the differences among diseases as they affect individual patients and the risk from epidemics and environmental conditions that affect the populations comprising human communities. Medicine's knowledge and wisdom comes from these patients and populations. Without them, medicine would be unable to provide high-quality care.

Correspondence: Robert E. Becker, MDCM, MA,

Aristea Translational Medicine Corporation,

3545 Cedar Drive, Park City, UT 84098

(rebecker@AristeaTM.com)
While patients may feel indebted to their doctors for correctly diagnosing and treating their illnesses, respecting their own individual points of view, and restoring and even improving their well-being, doctors are also rewarded in these encounters. They are rewarded by being able to pursue responsibly an honorable profession, earn a living for self and family, and, within the biological limits placed on life, provide health and freedom from suffering.

\section{What Can Be Learned From Patients?}

The doctor-patient relationship can be viewed in many ways. A realistic starting point is to see the patient as requiring a doctor's specialized services - assessment, advice, treatment, rehabilitation, and primary prevention. The patient also needs the doctor to gain knowledge and expertise so that the quality of each of these services grows. Less immediately appreciated in patient care is the expectation that medicine will continue its now centuries-long commitments to public health and the health of populations. Improving the public's health goes beyond the one-to-one doctor-patient relationship. Individuals comprising populations necessitate that this 
primary community health care delivery be provided in a thoughtful, sympathetic, and personalized way. Doctors learn practice from individuals, one-by-one, and in groups.

Even our age of great technological advances has not allowed modern life to escape unscathed from the scourge of epidemic infections or toxic environments. With technology permitting human expansion into wild habitats, with the reckless disposal of toxic waste, with manual labor and daily physical activity being replaced by technology, and with prepackaged foods substituting for homemade meals, medicine inherits populations afflicted by many diseases, both acute and chronic. Only through examining patients and their environments can doctors learn medicine and practice, and progressively improve their diagnostic and therapeutic skills.

This view of patients as teachers acknowledges that physicians can only learn through working with patients and communities. Preventive, diagnostic, and therapeutic medicine each involves the applications of theories gained from patient and population research. Medical skills also involve empathy, which may be gained by seeing the diversity of ills affecting diseased patients. We believe it is this implementation of theory modulated by a love and respect for humanity that leads to the understanding of the mechanisms of diseases, more effective treatments, improved outcomes and cures for previously untreatable diseases, and personal well-being.

Hippocrates was the first to state that doctors needed to learn from the idiosyncracies they saw in patients. The dawn of molecular genetics and the astonishing discovery that the DNA endowment of every individual was distinct from every other individual re-emphasized the uniqueness of each one of us. Patients are the doctor's best teachers because, though the disease may be the same across patients, its occurrence disturbs the homeostasis of each patient and her environment in a somewhat different way. Every patient brings a unique genetic and experiential history to every episode of disease, her response to the course of her disease, and to its treatment. Patients are our teachers because, though we can diagnose an illness (eg, give it a name without knowing a patient), we can only treat the illness effectively if we do know the patient and her specific illness.

\section{The Physician as Student}

In the 19th century two individuals grasped this unique aspect of medicine that sets it apart from the natural sciences. Charles Darwin found that a species was comprised of populations of unique individuals. Darwin's theory that the selection of adaptive traits was the engine of evolution threw a spotlight on the importance of these individual differences among members of a species: "I have called this principle, by which each slight variation, if useful, is preserved, by the term of Natural Selection." ${ }^{3}$ With this insight he could account for evolution in terms of a differential survival from generation to generation of those individuals best adapted to reproduce and pass on their resources. The observation of individual organisms, with the varying ways that each differed from others in the same species, in effect taught Darwin the principles of evolution.

To medicine, William Osler's observations were equally important: "The good physician treats the disease; the great physician treats the patient who has the disease."4 In Osler's view, one starts with, "Listen to your patient, he is telling you the diagnosis." ${ }^{4}$ Osler's cousin and student, W. W. Francis, and Osler's professional grandchildren at McGill taught us, the two authors of this work, the importance of thorough history-taking, careful observation, and painstaking physical examination (skills we feel are too often lacking today). Only then did one move on to the laboratory for confirmation of one's hypotheses, a resource for which Osler had great respect; he was the one who introduced microscope use into everyday patient care. ${ }^{5}$ Today, it can seem that clinicians tend to trust laboratory results more than their observational skills, although this may be changing. There are protests against fiscally based constraints on the time a physician spends with patients, and efforts are being made to recover lost physical diagnosis skills. ${ }^{6}$

Whether through history or physical examination or laboratory results, our patients continue to teach us. They are our tutors. This role needs to be recognized by the medical community and by the wider community that reaps the benefits of the teaching. Today's medicine appreciates the complicated interdependence that makes the provision of patient care and community health care more, much more, than a simple business transaction, even while political, commercial, and financial pressures are pushing medicine in that direction. ${ }^{7}$ 
Darwin revolutionized biology, and Osler revolutionized medicine. Each agreed with Osler's view that "Variability is the law of life." ${ }^{4}$ Osler explains that "no two faces are the same, so no two bodies are alike, and no two individuals react alike and behave alike under the abnormal conditions which we know as disease." "A disease imposes unmistakable, distinctive pathologies on each affected patient; however, the symptomatic and functional consequences for the patient differ from one individual to the next. ${ }^{5,9}$

This means that a) each patient has something to teach us, and b) physicians need to be lifelong students (as Osler recommended). One forever learns at the patient's bedside and on community streets. Medical science is learned in laboratories, through clinical studies, and through the reading of research reports, but, as Osler taught, "[Patient care] is learned by the bedside and not in the classroom." 10 This realization levels the playing field. Because we are all sometimes patients, "wounded healers," 11 we must make sure that the power interrelation, present but often unaddressed in the patient-doctor encounter, does not cloud the fact that our patients have much to teach us, if only we let them. One way to allow the patient to serve her teaching function is to recognize and acknowledge the power differential that exists and not permit it to interfere with the patient letting us learn.

\section{Patients as Guides to Healing}

The doctor heals, but only because the patient guides the way. Better understanding of the epigenome, with its multitude of chemical signals that reflect each person's unique growth and development, drives this point home. Even identical twins, who may start out the same, progressively differentiate from one another as they go through life. After the modern confirmation by molecular genetics of DNA inheritance, there is no question but that we all significantly differ and that our differences affect our medical care.

Today, doctors are responding to the role of being lifelong students by two advances. First, patient care and its supporting research are heading toward precision medicine, in which every patient-physician encounter becomes an $\mathrm{N}=1$ trial. Each trial outcome incrementally expands our scientific knowledge base and informs and improves patient care. Second, contemporary public health is refreshing itself by adopting teachings from Darwin's modern evolutionary biology. With the term "population thinking," biology acknowledges that populations are made up of individuals. Public health finds the concept of many individuals living in varying environments and thus comprising different populations to be a powerful source of insights into why certain persons and not others are affected by a disease. ${ }^{12}$

The wider community, all of whom will be patients at one time or another, collectively benefits when doctors are skilled and proficient; when they have the time and resources to attend to their patients on an individual basis; and when medicine can prevent some diseases, effectively treat those that cannot be prevented, and address the impairments, disabilities, and losses of well-being that often ensue after an illness has run its course. The whole community gains when doctors learn from their patients. Communities that are not aware that a learned profession such as medicine can become a learning profession might keep in mind Charles Darwin's concern: "If the misery of the poor be caused not by the laws of nature, but by our institutions, great is our $\sin . " 13$

The American Board of Internal Medicine (ABIM) has attempted to identify the virtues that all physicians need to possess. ${ }^{14}$ These virtues are a) excellence in the sense of maintaining competence in the delivery of highquality care; b) humanism, which includes a concern for humanity, a respect for the rights and choices of every person, and an ability to show compassion for suffering; c) altruism; and d) accountability. Each virtue speaks to the professional ability to put the needs of others ahead of one's own and the willingness to acknowledge responsibility for decisions and actions taken. Such decisions and actions need to be made, not only on behalf of individual patients but, most importantly, on behalf of one's community. ${ }^{15}$ That translates to the highest-quality patient care, supporting public health interventions aimed to prevent diseases and disabilities, and working to ensure equitable access to high-quality health care for all. A country cannot boast of its ability to provide the best medical care in the world if some members of the community, because of the "misery of [being] poor," cannot take advantage of it. Equity, fairness, advocacy, and respect for human dignity seem implied by the mission statement of the ABIM. ${ }^{14}$ 


\section{Voices From the Past}

To this end, role models are important. What better role models than Hippocrates, who reminds us to honor our teachers, Darwin, who informs us how much individual differences matter, and Osler, whose lifelong work emphasized the singularity of each patient and the permanent apprenticeship status of physicians? These voices from the past remind us that, while we differ importantly, we all share a vulnerability to suffering.

As students trained in Osler's Hippocratic tradition and from personal experience over the years, we the authors have found it useful to remember that patients are our teachers. Only through their individual stories do we ever bring to patients diagnosis, treatment, care, and improved well-being and they to each of us personal satisfaction as a physician. We need our patients to the same degree that they need us.

\section{Conflicts of Interest}

None.

\section{References}

1. Osler W. Books and men. In: Aequanimitas: With Other Addresses to Medical Students, Nurses and Practitioners of Medicine. Philadelphia, PA: P. Blakiston's Son \& Co., 1904, pp. 217-26.

2. Hippocrates. Oath. In: Jones WHS (ed). Hippocrates, Volume 1. Cambridge, MA: Harvard University Press, 1923, pp. 299-301.

3. Darwin C. On the Origin of Species by Means of Natural Selection. London: John Murray, 1959, p. 81.
4. Bean RB, Bean WB (eds). Sir William Osler: Aphorisms From His Bedside Teachings and Writings. Springfield, IL: Charles C. Thomas, 1961.

5. Becker RE. Remembering Sir William Osler 100 years after his death: what can we learn from his legacy? Lancet. 2014;384:2260-3. CrossRef

6. Mughal R. Bringing back bedside exams: the Stanford Symposium. Medscape.com (Epub 2017 Oct 4). https://www. medscape.com/viewarticle/886530. Accessed October 10, 2017.

7. Rosenthal E. An American Sickness. New York, NY: Penguin Press, 2017.

8. Osler W. On the educational value of the medical society. In: Aequanimitas: With Other Addresses to Medical Students, Nurses and Practitioners of Medicine. Philadelphia, PA: P. Blakiston's Son \& Co., 1904, pp. 343-62.

9. Seeman MV, Becker RE. Osler and the way we were taught. Med Sci Educ. 2017;27:555-7.

10. Thayer WS. Osler the teacher. In: Thayer WS (ed). Osler and Other Papers. Baltimore, MD: Johns Hopkins Press, 1931, pp. 1-15.

11. Frank AW. The Wounded Storyteller: Body, Illness, and Ethics, Second Edition. Chicago, IL: University of Chicago Press, 2013.

12. Wells JCK, Nesse RM, Sear R, Johnstone RA, Stearns SC. Evolutionary public health: introducing the concept. Lancet. 2017;390:500-9. CrossRef

13. Darwin C. Journal of Researches Into the Natural History and Geology of the Countries Visited During the Voyage of H.M.S. Beagle Round the World, Second Edition. London: John Murray, 1845, pp. 499-500. [Quoted in: Chambers W, Chambers R (eds). Slavery. Chambers's Edinburgh Journal. 1845;4(94):256.]

14. MacKenzie CR. Professionalism and medicine. HSS J. 2007;3:222-7. CrossRef

15. Barondess JA. Medicine and professionalism. Arch Intern Med. 2003;163:145-9. CrossRef

(C) 2018 Aurora Health Care, Inc. 